\title{
Threats to the Bengal slow loris Nycticebus bengalensis in and around Itanagar Wildlife Sanctuary, Arunachal Pradesh, India: impediments to conservation
}

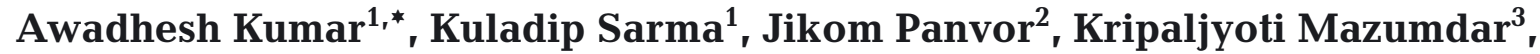 \\ Ashalata Devi ${ }^{4}$, Murali Krishna1 ${ }^{1}$ Parimal Chandra Ray ${ }^{1}$ \\ ${ }^{1}$ Department of Forestry, NERIST (Deemed University), Nirjuli-791109, Itanagar, Arunachal Pradesh, India \\ ${ }^{2}$ Biological Park, Itanagar-791101, Arunachal Pradesh, India \\ ${ }^{3}$ Centre for Micro-finance \& Livelihood (CML), 18, Bye Lane-3, Chandan Nagar Survey, Beltola, Guwahati-781 028, Assam, India \\ ${ }^{4}$ Department of Environmental Science, Tezpur University, Napaam-784028, Tezpur, Sanitpur Assam, India
}

\begin{abstract}
The present study provides data collected during rescue operations involving Bengal slow loris Nycticebus bengalensis which were carried out opportunistically in and around Itanagar Wildlife Sanctuary, Arunachal Pradesh, India. A total of 27 individuals consisting of 21 males and 6 females were rescued from the study sites; $81 \%$ of these were adult and $19 \%$ sub-adult. Of the 27 individuals, 12 were rescued from private gardens. All rescued individuals were kept under observation in the Biological Park zoo situated within the sanctuary, where they received the necessary treatment, and were then released to the wild in the sanctuary. Various anthropogenic threats were recorded in the study; these included illegal logging, firewood collection, forest fires and habitat encroachment to enable the traditional practice of shifting cultivation, and infrastructural developmental activities. The present study highlights factors impeding the conservation of slow loris in and around the sanctuary.
\end{abstract}

KEY WORDS: Nocturnal primates $\cdot$ Habitat encroachment $\cdot$ Hunting $\cdot$ Pristine habitat $\cdot$ Vulnerable Resale or republication not permitted without written consent of the publisher

\section{INTRODUCTION}

Primates are reliant on primary forest habitats, where they play a fundamental role in forest ecosystems as seed dispersers and predators (Chapman \& Onderdonk 1998, Kays \& Allison 2001). Habitat structure, quality and anthropogenic disturbance are known to affect primate diversity and abundance in tropical forests (Rylands 1987, Chapman \& Peres 2001, Pyritz et al. 2010). Thus, any kind of habitat alteration or disturbance elicits varied levels of responses among primate species (Schwitzer et al. 2011). Some primate species react to disturbance by temporary or permanent emigration, crowding tendencies or altered sex ratios, while others continue to remain in the same area despite anthropogenic threats (Marsh et al. 1987, Chiarello \& De Melo 2001, Peres 2001, Baranga 2004, Martins 2005, Rode et al.
2006, Schwitzer et al. 2011). Animals living in disturbed, degraded or fragmented habitats may also face reduced food resources, loss of roosting sites, escape cover and migratory routes (Kumar \& Solanki 2004, Malhi et al. 2008, Sarma et al. in press) and may become more vulnerable to natural disasters such as hurricanes, floods or to changes resulting from global climate change, such as seasonal droughts (Malhi et al. 2008, Alho \& Silva 2012). Harcourt \& Doherty (2005) stated that primate richness generally decreases with fragment size. However, in some highly fragmented or isolated small forest patches $\left(<50 \mathrm{~km}^{2}\right)$ primate densities have been found to increase, possibly owing to the absence of main predators such as large cats and birds of prey (González-Solís et al. 2001), the density compensation phenomenon (Peres \& Dolman 2000), and the ecological plasticity of some primate species 
(González-Solís et al. 2001). Laurance et al. (2006, 2008) reported that both nocturnal and diurnal species within the same community may respond differently to habitat disturbance.

Bengal slow loris Nycticebus bengalensis is found in India, Bangladesh, Bhutan, Myanmar, Cambodia, southern China, Lao PDR, northern Thailand, and Vietnam (Brandon-Jones et al. 2004, IUCN 2008). In India, the species is confined to the 7 northeastern states (Choudhury 1992, Srivastava 1999, BrandonJones et al. 2004, Radhakrishna et al. 2006, Swapna et al. 2008, Das et al. 2009, Nandini et al. 2009, Kumar \& Devi 2010) and is reported to occur in tropical, subtropical evergreen, semi-evergreen and moist deciduous forests (Choudhury 2001, Swapna et al. 2008). Habitat destruction and disturbance due to shifting cultivation, encroachment, selective logging, road kills, bushmeat hunting and forest fire have been reported as major threats to the slow loris population in northeast India (Choudhury 1992, Srivastava 1999, Radhakrishna et al. 2006, Kumar \& Devi 2010). As a result of these threats, slow loris is listed in Schedule I of the Indian Wildlife (Protection) Act, 1972. It has also been categorized as Vulnerable (A2cd ver 3.1) in the IUCN Red List (IUCN 2008) and listed in Appendix I of CITES.

Bengal slow lorises prefer forest edges because of the seasonal high density of insect prey found there (Rowe 1996). Thus, any kind of disturbances such as clear felling and burning for shifting cultivation (jhum) at the forest edge increases the vulnerability of the species and forces individuals to move towards secure habitat for survival (Radhakrishna et al. 2006, Kumar 2009). However, more data are needed to determine the full extent to which the species is affected by such disturbances. Only a few field studies (Mishra et al. 2006, Radhakrishna et al. 2006, Swapna et al. 2008, Biswas et al. 2009, Das et al. 2009) have been conducted in the last decade in northeast India which confirm the presence of Bengal slow lorises in disturbed (fragmented) and undisturbed habitats and also highlight the conservation issues.

Bengal slow loris populations have been declining due to escalating habitat destruction in the form of shifting cultivation, the construction of roads, houses, hydro-electric dams, development of orchards, anthropogenic forest fires, hunting, road accidents, and the medicinal and pet trades (Wolfheim 1983, Srivastava 1999, Srivastava \& Mohnot 2001, Radhakrishna et al. 2006, Nekaris \& Bearder 2007, Nekaris et al. 2008, Das et al. 2009, Kumar \& Devi 2010). Hunting and deforestation have been reported as the 2 prime threats to the continued existence of the species
(Choudhury 1992, Srivastava 1999). A few studies have described rescues of slow lorises affected by habitat disturbances in northeast India (Radhakrishna et al. 2006, Biswas et al. 2009, Kumar 2009, Nandini et al. 2009). Here, we present the data of Bengal slow loris rescued from 1996 to 2012 in and around the Itanagar Wildlife Sanctuary, Arunachal Pradesh, India.

\section{MATERIALS AND METHODS}

\section{Study area}

The study was conducted in and around the Itanagar Wildlife Sanctuary (IWLS) in the Papum Pare district of Arunachal Pradesh. The sanctuary $\left(27^{\circ}\right.$ $05^{\prime} 39^{\prime \prime} \mathrm{N}, 93^{\circ} 30^{\prime} 15^{\prime \prime} \mathrm{E}$ ) covers an area of $140.8 \mathrm{~km}^{2}$ and is located in the vicinity of the capital city of Arunachal Pradesh, Itanagar, and bordered by the Poma River in the east, the Pachin River in the south and the Neorch River in the northwest (Fig. 1). The terrain is rugged with steep slopes and dense vegetation and the altitude ranges from 250 to $2000 \mathrm{~m}$ above sea level (a.s.1.). The forest in the sanctuary is wet and semi-evergreen with a multistoried structure consisting of a large number of species belonging to different families and genera (Kaul \& Haridasan 1987, Srivastava \& Choudhary 2006).

\section{Methods}

The study is a compilation of data collected from 1996 to 2012 during rescue operations carried out opportunistically by the authors and Biological Park (zoo), Hanagar, forest staff. Information regarding the occurrence of slow lorises in human-dominated areas was received from local people. The slow loris is well known among the local people in the state, who hold the superstitious belief that the presence of the species is an ill omen; they thus tended to inform forest officials and the authors about any occurrence of the species in their locality. Immediately after the information was received, the sites were visited with a view to rescuing the individuals. Animals were kept for behavioural observation for 5 to $6 \mathrm{~d}$ at the Biological Park, Itanagar, where they received all necessary treatment. The rescued animals were released in the IWLS when this was convenient. Habitat disturbance data were collected from the slow loris occurrences reported by the local people and as a result of direct observations. 

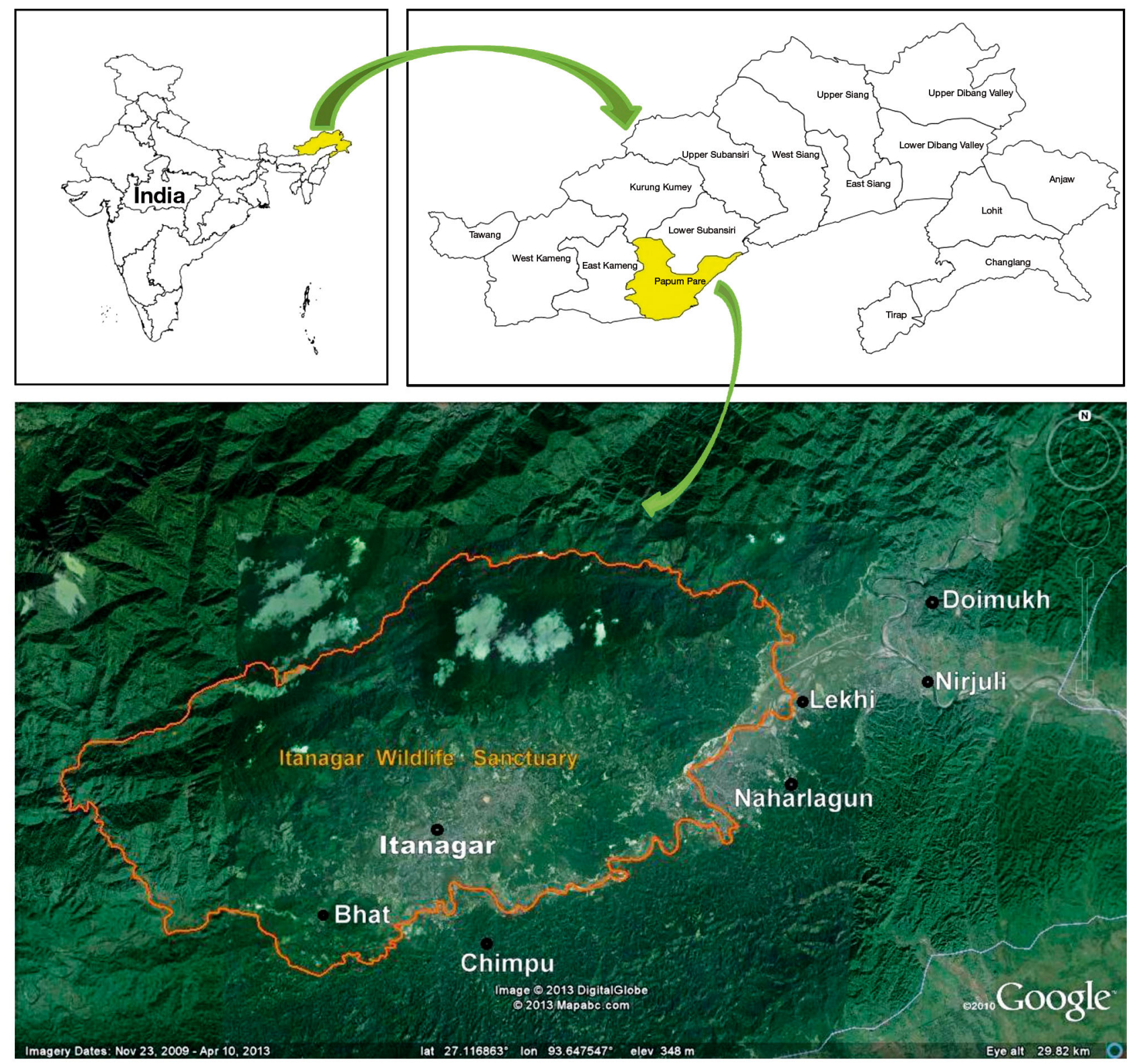

Fig. 1. Itanagar Wildlife Sanctuary highlighting the human-dominated areas from which Nycticebus bengalensis was rescued

\section{RESULTS}

\section{Lorises rescued}

A total of 27 individuals of Nycticebus bengalensis were rescued from the villages (human-dominated landscape) located in and around IWLS (Table 1). Of the total, $21(78 \%)$ were male and $6(22 \%)$ were female; $81 \%(\mathrm{n}=22)$ were adult and $19 \%(\mathrm{n}=5)$ were sub-adult. Of the 22 adults, $81 \%(n=18)$ were males and $19 \%(n=4)$ females; of the sub-adults recorded $60 \%(n=3)$ were males and $40 \%(n=2)$ females. The largest number of individuals $(\mathrm{n}=8)$ were rescued from Itanagar, the smallest number (n = 1) from Bhat village. A high proportion $(44 \%, \mathrm{n}=$ 12) of individuals were rescued from the gardens situated near the disturbed forest areas such as jhumcultivated lands or forest destroyed by highway and commercial building construction, followed by $37 \%$ ( $\mathrm{n}=10$ ) from inside local houses, $11 \%(\mathrm{n}=3)$ from roadside plantations and $7 \%(\mathrm{n}=2)$ on the forest edges during the evening (Fig. 2). Dividing the study period into 3 yr spans, numbers were highest in 2010-2012 (33\%, n = 9), followed by 2001-2004 
$(30 \%, \mathrm{n}=8), 1996-2000(26 \%, \mathrm{n}=7)$ and $2004-2009$

$(11 \%, \mathrm{n}=3)$ (Fig. 3).

\section{Release of lorises}

Slow lorises were removed from the rescue sites and taken to the Biological Park (zoo) at Itanagar, Arunachal Pradesh. They were kept in cages for 5 to $6 \mathrm{~d}$ for observation under the constant supervision of a veterinary officer. The necessary treatment was given to injured animals until they recovered. Of the 27 rescued slow lorises, 4 individuals were kept at the zoo for conservation breeding and to serve the purpose of educating local people about the species the others were released back into the wild in the core area of the sanctuary.

\section{Conservation issues}

Various anthropogenic threats including forest encroachment for developmental activities, and habitat disturbance in terms of illegal logging, firewood collection and shifting cultivation were recorded in and around the IWLS, particularly in the fringe area of the state capital city Itanagar, Arunachal Pradesh (Fig. 4). However, activities such as construction of roads and highways, multi-storied commercial and residential complexes, petrol pumps, and tea gardens contributed more to the process of habitat encroachment. Practices such as slow loris hunting, poaching and keeping live animals as pets was not observed in the study area because of superstitious beliefs among locals. The local people believe that the species brings misfortune to the family once it enters their premises as well as that its bite

Table 1. Nycticebus bengalensis. Details of rescued slow loris individuals SL: slow loris

\begin{tabular}{|llccccc|}
\hline $\begin{array}{l}\text { SL } \\
\text { no. }\end{array}$ & Location & $\begin{array}{c}\text { No. of animals } \\
\text { rescued }\end{array}$ & \multicolumn{2}{c}{$\begin{array}{c}\text { Adults } \\
\text { Males }\end{array}$} & $\begin{array}{c}\text { Females } \\
\text { Males Females }\end{array}$ \\
\hline 1 & Doimukh & 5 & 2 & 1 & 2 & - \\
2 & Chimpu & 6 & 3 & 2 & - & 1 \\
3 & Itanagar & 8 & 6 & 1 & 1 & - \\
4 & Lekhi Village & 2 & 2 & - & - & - \\
5 & Naharlagun & 3 & 3 & - & - & - \\
6 & Nirjuli & 2 & 1 & - & - & 1 \\
7 & Bhat Village & 1 & 1 & - & - & - \\
Total & & 27 & 18 & 4 & 3 & 2 \\
Percentage (\%) & & 67 & 15 & 11 & 7 \\
\hline
\end{tabular}

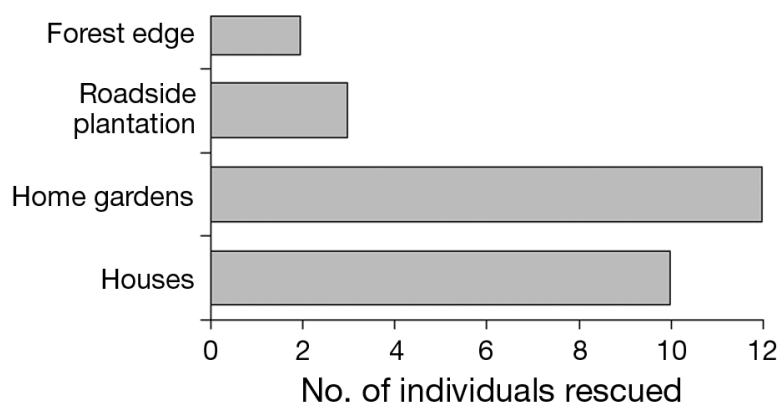

Fig. 2. Nycticebus bengalensis. Locations in and around the Itanagar Wildlife Sanctuary from which Bengal slow lorises were rescued

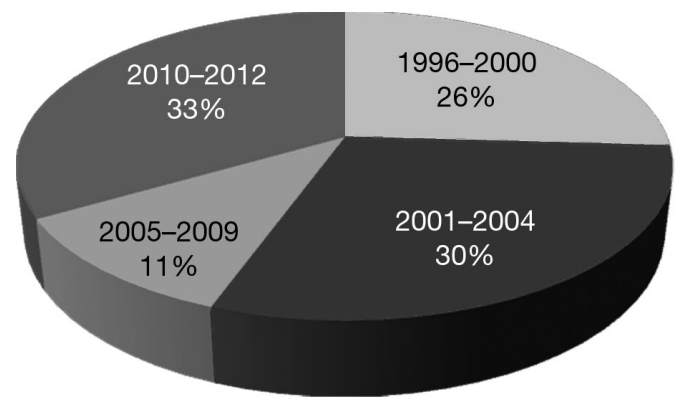

Fig. 3. Nycticebus bengalensis. Rescue statistics for slow loris for 1996 to 2012 in and around the Itanagar Wildlife Sanctuary

is poisonous. One of the authors (J.P.) was bitten on the finger during a rescue operation, and pain and swelling were recorded at the site of the bite. One more incident of biting was observed while rescuing an animal. In this case, there was a severe allergic reaction throughout the body and the person was hospitalized for a week. However, contrary to the belief of the local people, the bite of the species is not poisonous; it may sometimes cause an allergic reaction, which may in some cases lead to an anaphylactic shock. Wilde (1972) also reports that the victim of a slow loris bite immediately succumbs to anaphylactic shock followed by hematuria. Slow loris bites are rarely reported. However, based on our observations and published reports (Wilde 1972, Kalimullah et al. 2008), it seems that they are not poisonous. Nonetheless, due to the production of exudate from the brachial gland of the slow loris, which is similar to the Fel d 1 cat allergen, the anaphylactic shock experienced by vic- 


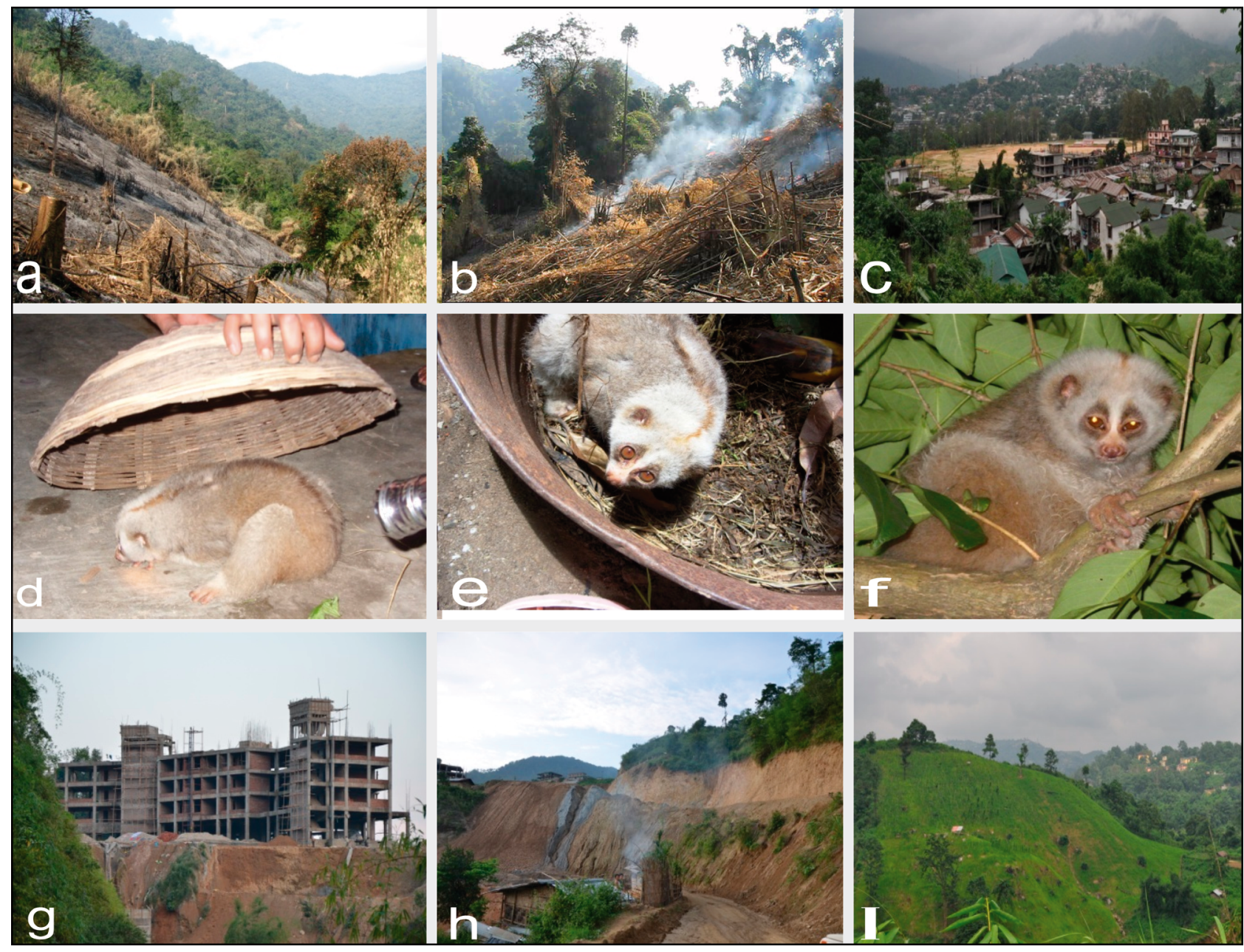

Fig. 4. Nycticebus bengalensis. Major threats to slow lorises in and around the Itanagar Wildlife Sanctuary (IWLS): (a) forest cutting for shifting cultivation; (b) anthropogenic forest fire; (c) rapid expansion of urban areas in and around IWLS; (d,e) rescue of slow loris from local house; (f) slow loris in garden of local people; (g) construction of commercial complex near the IWLS; (h) highway construction; (i) shifting cultivation in and around the IWLS

tims is probably just a reaction to the exudate's allergen (Krane et al. 2003, Hagey et al. 2007).

\section{DISCUSSION}

Nycticebus bengalensis rescued from a humandominated landscape is a subject of great interest. The increasing human population is intensifying the degradation of the pristine habitat of $N$. bengalensis throughout the northeast of India, which might compel the animals to migrate in search of food and shelter. Such a temporary migration of the species was reported from Assam by Radhakrishna et al. (2006), who found that $N$. bengalensis migrates toward the edges of the forest in response to habitat disturbance.
Similarly, other species such as N. coucang have also been reported to move to the outer edges of the forest in response to logging pressure (Johns 1986). However, the other northeast states of India contribute to the rescue statistics for $N$. bengalensis. Radhakrishna et al. (2006) reported the rescue of a significant number of $N$. bengalensis (14 individuals over a span of $6 \mathrm{yr}$ ) from the 3 districts of Assam, viz. Tinsukia, Golaghat and Karbi Anglong. Biswas et al. (2009) also reported the rescue of 5 slow lorises from DibruSaikhowa National Park and Amchang Wildlife Sanctuary in Assam, which were then either kept in a zoo or released in protected forest. Nandini et al. (2009) reported a case in which the species was kept as a captive pet in Assam and Meghalaya, which were later released into nearby forest patches. 
Kumar \& Devi (2010) rescued an adult male slow loris from a roadside plantation of the NERIST university campus, Nirjuli, Arunachal Pradesh. The campus is surrounded by hills where jhum cultivation is practised. This rescued slow loris might have migrated from its original habitat due to a high degree of disturbance and threats posed by forest cutting, forest burning for jhum cultivation and used the home gardens, roadside plantation, tea garden and fragmented small forest patches as stepping stone to migrate in search of food and safe shelter. We observed that slow lorises entered the premises of locals in search of food (eggs) during the night. Most of the animals rescued were from backyard poultry houses. From observations made during the study, it seems that it is mostly the males which gather food for the family.

Over the last few decades, forest encroachment in and around IWLS for various purposes has increased the species' vulnerability. Although slow loris hunting has not been observed in Arunachal Pradesh, the species is hunted by inhabitants of other northeast Indian states for use as traditional medicine and as bushmeat (Southwick \& Siddiqi 2001, Chetry et al. 2003, Radhakrishna \& Sinha 2004, Biswas et al. 2009). Similarly, slow lorises are also captured and hunted in their global distribution range for food, to be kept as pets and for use in traditional medicine (Martin \& Phipps 1996, Duckworth et al. 1999, Long et al. 2004, Walston 2005, Ashwell \& Walston 2008, Nekaris et al. 2008, China Species Information Service unpubl. data).

The rescue of Nycticebus bengalensis from the human-dominated landscape is very important from a conservation point of view, particularly in Arunachal Pradesh, India, where jhum cultivation is the primary source of livelihood of the tribal people, and infrastructure development work is primarily a source of income for the more wealthy. Choudhury (2001) reported that the forest cover of northeast India is disappearing at an alarming rate, and in some areas more than $55 \%$ of the formerly dense canopy has been lost (Southwick \& Siddiqi 2001, Ramakantha et al. 2003). MacKinnon \& MacKinnon (1987) reported about $75 \%$ habitat loss of slow lorises in the Indo-Chinese region as a result of various anthropogenic threats similar to those in India.

Slow lorises are mostly threatened by hunting, habitat fragmentation and destruction in the form of shifting cultivation, accidental forest fire, encroachment for permanent settlement, construction of buildings, roads, bridges, road accidents and illegal timber logging as well as trading of live specimens
(Choudhury 1992, Ahmed 2001, Singh 2001, Southwick \& Siddiqi 2001, Chetry et al. 2003, Walker \& Molur 2004, Radhakrishna \& Sinha 2004, Ghose \& Kaul 2005, Radhakrishna et al. 2006, Biswas et al. 2009, China Species Information Service unpubl. data) in this region. These factors are contributing to the decline of the slow loris population in Arunachal Pradesh and represent the most serious threats to the survival of the species worldwide (Southwick \& Siddiqi 2001, Srivastava \& Mohnot 2001, Walker \& Molur 2004, Long et al. 2004, Ghose \& Kaul 2005). Huy Huynh (1998) and Thanh (2002) also report that wild populations have declined critically and that further local extinctions are feared in some areas of the species' distribution range.

The major difficulty involved in releasing the animal into the wild is the lack of information on its habitat requirements. An arbitrary release may lead to the death of the animali thus, it is imperative for the development of meaningful slow loris conservation strategies that more information should be obtained on habitat variables and population densities throughout the species' range (Radhakrishna et al. 2010).

\section{CONCLUSION AND RECOMMENDATION}

Throughout its global distribution range, and in northeast India in particular, the Bengal slow loris is affected by habitat encroachment and disturbances due to jhum cultivation, selective logging, development activities, and hunting. Reports of slow lorises in captivity are numerous throughout the range of these animals, including northeastern India (Nandini et al. 2009), especially in tribal-dominated areas (Duckworth et al. 1999). Conservation of this little studied primate species must be directed towards the mapping of their important habitats in the region and the assessment of the population in the disturbed and the undisturbed habitat ranges. The species' occurrence at the forest edge and in human-modified landscape should be ecologically analyzed to initiate an appropriate conservation management programme. Nandini et al. (2009) recommended forest corridors connecting disturbed habitat as an important conservation measure. Fuller et al. (2006) suggested the need for effective conservation plans which take into account both the need for protected area connectivity and the requirements of the local human population (Gillingham \& Lee 1999), possibly through multi-criteria analysis (Moffett \& Sarkar 2006) and ecological niche modeling (Thorn et al. 
2009). It is necessary to raise awareness among the tribal people of Arunachal Pradesh for wildlife species, particularly for primate species such as the slow loris, which act as seed dispersal agents and which prey on several forest insect species (biological control). In addition, the need for the conservation and protection of the tropical forest ecosystem should be made clear to help ensure the future survival of the species. Local government should initiate appropriate steps to control unplanned developmental activities in and around the forest area of the sanctuary.

Acknowledgements. We thank the Biological Park, Itanagar, for providing information regarding the rescue of Bengal slow lorises and the local people who live in and around the IWLS for their generous help and support. We also thank Raju Barthakur, Assistant Professor, NERIST, for improving the English and 3 anonymous reviewers for their critical comments which improved the quality of the manuscript.

\section{LITERATURE CITED}

Ahmed A (2001) Illegal trade and utilization of primates in India. ENVIS Bull 1:177-184

> Alho CJR, Silva JSV (2012) Effects of severe floods and droughts on wildlife of the Pantanal wetland (Brazil) - a review. Animals 2:591-610

Ashwell D, Walston N (2008) An overview of the use and trade of plants and animals in traditional medicine systems in Cambodia. TRAFFIC Southeast Asia, Greater Mekong Programme, Ha Noi

> Baranga D (2004) Red tail monkey groups in forest patches outside the protected area systems in Kampla Area. Afr J Ecol 42:78-83

Biswas J, Das N, Borah DK, Sangma A, Ray PC, Das J (2009) Status and distribution of least known primate species: slow loris and capped langur in the Protected Areas of Assam, India and its feeding ecology. In: Biswas J (ed) Final Report of Primate Research Centre NE India, Wildlife Information Liaison Development, Zoo Outreach Organization and Margot Marsh Biodiversity Foundation Collaborative Project No. PRCNE/Tecr-7, p 1-39

Brandon-Jones D, Eudey AA, Geissmann T, Groves CP and others (2004) Asian primate classification. Int J Primatol 25:97-164

> Chapman CA, Onderdonk DA (1998) Forests without primates: Primate/Plant codependency. Am J Primatol 45 127-141

> Chapman CA, Peres CA (2001) Primate conservation in the new millennium: role of scientists. Evol Anthropol 10: 16-33

> Chetry D, Medhi R, Biswas J, Das D, Bhattacharjee PC (2003) Nonhuman primates in the Namdapha National Park, Arunachal Pradesh, India. Int J Primatol 24 383-388

> Chiarello AG, De Melo FR (2001) Primate population densities and sizes in Altantic Forest remnants of Northern Espiritu Santo, Brazil. Int J Primatol 22:379-396

Choudhury AU (1992) The slow loris (Nycticebus coucang) in northeast India. Primate Rep 34:77-83
Choudhury A (2001) Primates in northeast India: an overview of their distribution and conservation status. ENVIS Bull 1:92-101

- Das N, Biswas J, Das J, Ray PC, Sangma A, Bhattacharjee PC (2009) Status of Bengal slow loris Nycticebus bengalensis (Primates: Lorisidae) in Gibbon Wildlife Sanctuary, Assam, India. JOTT 1(11):558-561

Duckworth JW, Salter RE, Khounboline K (1999) Wildlife in Lao PDR: 1999 Status Report. Vientiane: IUCN-The World Conservation Union/Wildlife Conservation Society/Centre for Protected Areas and Watershed management. Samsaen Printing, Bangkok

Fuller T, Muguia M, Mayfield M, Sanchez Cordero V, Sarkar $S$ (2006) Incorporating connectivity into conservation planning: a multi criteria case study from central Mexico. Biol Conserv 133:131-142

Ghose D, Kaul R (2005) Conservation implications of wild animal biomass extractions in Northeast India. Anim Biodivers Conserv 28:169-179

Gillingham S, Lee PC (1999) The impact of wildlife related benefits on the conservation attitude of local people around the Selous Game Reserve. Tanzania. Environ Conserv 26:218-228

> González-Solís J, Guix JC, Mateos E, Llerens L (2001) Population density of primates in large fragments of the Brazilian Atlantic rainforest. Biodivers Conserv 10:1267-1282

Hagey LR, Fry BG, Fitch-Snyder H (2007) Talking defensively: a dual use for the brachial gland exudate of slow and pygmy lorises. Prim Anti-Pred Strat 2:253-272

Harcourt AH, Doherty DA (2005) Species area relationships of primates in tropical forest fragments: a global analysis. J Appl Ecol 42:630-637

Huy Huynh DH (1998) Ecology, biology and conservation status of Prosimian species in Vietnam. Folia Primatol 69: 101-108

IUCN (2008) 2008 IUCN Red List of Threatened Species. IUCN SSC, Gland. www.iucnredlist.org (accessed 18 August 2012)

Johns DA (1986) Effect of selective logging on the behavioral ecology of west Malaysian primates. Ecology 67: 684-694

Kalimullah EA, Schmidt SM, Schmidt MJ, Lu JJ (2008) Beware the pygmy slow loris? Clin Toxicol 46:602

Kaul RN, Haridasan KC (1987) Forest types of Arunachal Pradesh-a preliminary study. J Econ Taxon Bot 9: 379-389

Kays RW, Allison A (2001) Arboreal tropical forest vertebrates: current knowledge and research trends. Plant Ecol 153:109-120

Krane S, Itagaki Y, Nakanishi K, Weldon PJ (2003) 'Venom' of the slow loris: sequence similarity of prosimian skin gland protein and Fel d 1 cat allergen. Naturwissenschaften 90:60-62

Kumar A (2009) Endangered slow loris's journey from NERIST to Itanagar Biological Park. The Arunachal Times: 1$2,17.05 .09$

Kumar A, Devi A (2010) Status and conservation of slow loris Nycticebus bengalensis in northeast India. Ecotone 2: 18-20. www.scribd.com/doc/32168876/Ecotone2-1-2010

> Kumar A, Solanki GS (2004) A rare feeding observation on water lilies (Nymphaea alba) by capped langur (Trachypithecus pileatus). Folia Primatol (Basel) 75:157-159

Laurance WF, Croes BM, Tchignoumba L, Lahm SA and others (2006) Impacts of roads and hunting on central African rainforest mammals. Conserv Biol 20:1251-1261 
Laurance WF, Croes BM, Guissouegou N, Buij R, Dethier M Alonso A (2008) Impacts of roads, hunting, and habitat alteration on nocturnal mammals in African rainforests. Conserv Biol 22:721-732

Long B, Hoang M, Hardcastle J, Baltzer M, Truyen T (2004) Incorporating primate conservation into provincial policy and practice. WWF Indochina, Hanoi, http://assets. panda.org/downloads/longetal2004.pdf

MacKinnon J, MacKinnon K (1987) Conservation status of the primates of the Indo-Chinese subregion. Prim Conserv 8:187-195

Malhi Y, Roberts JT, Betts RA, Killeen TJ, Li W, Nobre CA (2008) Climate change, deforestation and the fate of the Amazon. Science 319:169-172

Marsh CW, Johns AD, Ayres JM (1987) Effects of habitat disturbances on rainforest primates. In: Marsh CW, Mittermeier R (ed) Primate conservation in the tropical rainforest. Alan R. Liss, New York, NY, p 83-107

Martin E, Phipps M (1996) A review of the wild animal trade in Cambodia. TRAFFIC Bull 16:45-60

Martins MM (2005) Density of primates in four semi-deciduous forest fragments of Sao Paulo, Brazil. Biodivers Conserv 14:2321-2329

Mishra C, Madhusudan MD, Datta A (2006) Mammals of the high altitudes of western Arunachal Pradesh, eastern Himalaya: an assessment of threats and conservation needs. Oryx 40:29-35

Moffett A, Sarkar S (2006) Incorporating multiple criteria into the design of conservation area networks: a minireview with recommendations. Divers Distrib 12:125-137

Nandini R, Kakati K, Ved N (2009) Occurrence records of the Bengal slow loris (Nycticebus bengalensis) in northeastern India. Asian Primate J 1:12-18

Nekaris KAI, Bearder SK (2007) The lorisiform primates of Asia and mainland Africa: diversity shrouded in darkness. In: Campbell CJ,Fuentes A,Mackinnon KC, Panger M, Bearder SK (eds) Primates in perspective. Oxford University Press, Oxford, p 24-45

> Nekaris KAI, Blackham GV, Nijman V (2008) Conservation implications of low encounter rates of five nocturnal primate species (Nycticebus spp.) in Asia. Biodivers Conserv 17:733-747

Peres CA (2001) Synergistic efforts of subsistence hunting and habitat fragmentation on Amazonian forest vertebrates. Conserv Biol 15:1490-1505

> Peres CA, Dolman PM (2000) Density compensation in neotropical primate communities: evidence from 56 hunted and nonhuman Amazonian forests of varying productivity. Oecologia 122:175-189

Pyritz LW, Buntge ABS, Sebastian KH, Kessler M (2010) Effects of habitat structure and fragmentation on diversity and abundance of primates in tropical deciduous forests in Bolivia. Int J Primatol 31:796-812

Radhakrishna S, Sinha A (2004) Population survey and conservation of the Bengal slow loris in Assam and Meghalaya, north-eastern India. Ecology, Behaviour and Conservation Group. National Institute of Advanced Studies, Bangalore

> Radhakrishna S, Goswami AB, Sinha A (2006) Distribution and Conservation of Nycticebus Bengalensis in Northeastern India. Int J Primatol 27:971-982
Radhakrishna S, Datta-Roy A, Swapna N, Sinha A (2010) Population survey of the Bengal slow loris, Nycticebus bengalensis, in Meghalaya, northeast India. Primate Conserv 25:105-110

Ramakantha V, Gupta AK, Kumar A (2003) Biodiversity of northeast India - an overview. In: Gupta AK, Kumar A, Ramakantha V (eds) Wildlife and protected areas, conservation of rainforests in India. ENVIS Bull 4(1):1-24

Rode KD, Chapman CA, McDowell LR, Stickler C (2006) Nutritional correlates of population density across habitats and logging intensities in Red tail monkeys (Cercopithecus ascanius). Biotropica 38:625-634

Rowe N (1996) A pictorial guide to the living primates. Pogonias Press, New York, NY

Rylands AB (1987) Primate communities in Amazonian forests: their habitats and food resources. Experientia 43: 265-279

Sarma K, Krishna M, Kumar A (in press) Fragmented populations of Eastern Hoolock Gibbon Hoolock leuconedys in Lower Dibang Valley district in the state of Arunachal Pradesh, India. Oryx

Schwitzer C, Glatt L, Nekaris KAI, Ganzhorn JU (2011) Responses of animals to habitat alteration: on overview focussing on primates. Endang Species Res 14:31-38

Singh D (2001) Status and distribution of primates in Arunachal Pradesh. ENVIS Bull 1:113-119

Southwick C, Siddiqi M (2001) Status, conservation and management of primates in India. ENVIS Bull 1:81-91

Srivastava A (1999) Primates of Northeast India. Megadiversity Press, Bikaner

Srivastava RC, Choudhary RK (2006) Floristic scenario of Itanagar Wildlife Sanctuary-a case study. Bull Arunachal For Res 22:17-21

Srivastava A, Mohnot S (2001) Distribution, conservation status and priorities for primates in northeast India. ENVIS Bull 1:102-108

Swapna N, Gupta A, Radhakrishna S (2008) Distribution survey of Bengal slow loris Nycticebus bengalensisin Tripura, northeastern India. Asian Primates J 1:37-40

Thanh V (2002) The status and conservation of the loris species, Nycticebus coucang and N. pygmaeus, in Viet Nam. XIXth Congress of the International Primatological Society, 4th-9th August 2002, Beijing, China. Abstract p 254, International Primatological Society

Thorn JS, Nijman V, Smith D, Nekaris KAI (2009) Ecological niche modelling as a technique for assessing threats and setting conservation priorities for Asian slow lorises (Primates: Nycticebus). Divers Distrib 15:289-298

Walker S, Molur S (2004) Summary of the status of Southeast Asian primates. Extracted from the CAMP 2003 Report, 2nd edn. Zoo Outreach Organization, CBSG-South Asia and WILD, Coimbatore

WFT (2005) Report on wildlife rescue and releases of lorises. Wildlife Friends of Thailand, Petchaburi. www.wfft.org (accessed 28th March 2006)

Wilde H (1972) Anaphylactic shock following bite by a 'slow loris', Nycticebus coucang. Am J Trop Med Hyg 21: 592-594

Wolfheim J (1983) Primates of the world. Distribution, abundance and conservation. University of Chicago Press, Oxford

Submitted: August 24, 2012; Accepted: August 23, 2013

Proofs received from author(s): December 20, 2013 